\title{
Hidden for Their Protection
}

\section{Gendered Power, Provocation, and Representation in Dangdut}

Competition Television

\author{
Andrea Decker \\ University of California, Riverside \\ adeckoo3@ucr.edu
}

\begin{abstract}
Dangdut, Indonesia's most popular music genre, is a realm of gender contestation. Since the 199os, the role of professional dangdut singer-once equally filled by men and women - has been dominated by women. In an atmosphere of increasing Islamic fervour, pious consumption, and moral panic, the public perception of gender and sexuality has serious implications for men who sing dangdut on television. Regardless of their gender identity and sexual orientation, male singers must prove themselves to be properly gendered to maintain their positions as entertainers. However, proper masculinity is a difficult target to hit, especially considering the gender diversity of offair and backstage realities. Men use several tactics to boost perceptions of masculinity and acceptability. One way in which men who sing dangdut endeavour to prove themselves cowok banget, or super manly, is by employing symbols of Islam and the Middle East—-filtered through an Indonesian lens_- to communicate masculinity.
\end{abstract}

\section{Keywords}

dangdut - popular music - television - gender - sexuality

\section{Introduction: Performing Gender While Performing Dangdut}

It was the grand finale of Dangdut Academy Asia, a dangdut singing competition on the channel Indosiar, and contestant Reza ${ }^{1}$ had already advanced to

1 In Indonesia, people are often referred to by one name only. I here use the first names most commonly used by artists, rather than last names, when shortening names. 
the top three. As part of this grand finale concert, each contestant sang a duet with a jury member. Reza sang with Nassar, a brilliant young singer and past competition winner. The two men chose a single of Nassar's, 'Gejolak asmara', a dangdut song to which Nassar and the composer, Adibal, have self-consciously added Arab music elements, the 'dut' of dangdut drum rhythms replaced with the mellow Arab 'dum' sound. In the live duet, Reza added an extended intro section, using simple Arabic phrases like 'O Habibi' as well as 'I love you, I need you' in English to show off his skills in singing florid passages in foreign languages. Reza and Nassar sang to each other: 'Your smile completely charms me / your face is beautiful / wherever I look / it's only you that's reflected'; Reza extended his hand to Nassar, who took it and held it in the air in triumph.

A few months later, Dangdut Pantura, another singing-competition show on Indosiar with all the same jury members, was auditioning contestants. A presenter dramatically announced the next singer: Jus Geboy (see Figure 1). He sang the opening phrase from behind a screen: 'Para penonton ...' (Ladies and gentlemen ...). The audience immediately applauded as they recognized the song: 'Goyang Inul' by Inul Daratista, the woman whose dancing set off a debate in the early 2000 about sexuality and public discourse in post-New Order Indonesia. ${ }^{2}$ Inul happened to be one of the jury members, and the camera cut to her reaction. Jus Geboy continued: 'Ladies and gentlemen, all of you / don't be surprised if I start to dance / and it's hot / a little sexy / please forgive me.' He then emerged from behind the screen to confirm what we as the audience suspected: he is a man singing a song famously meant to be sung by a woman. Jus Geboy began to dance energetically, shaking his hips in an imitation of Inul's erotically feminine 'drill' dance. The camera showed Nassar, still in his position as jury member, jumping to his feet, laughing. The jury loved Geboy. They laughed, marvelled at his energy, and even had him show off his dancing ability after the song ended. But not a single one selected him as a contestant. Jus Geboy's performance was acceptable for a laugh, but he was barred from continuing on the show, while Reza and Nassar's performance was accepted. However, Jus Geboy's career continued to grow off-air, despite his on-air rejection; within a year he was opening for superstar Via Vallen.

Since the 199os, the role of professional dangdut singer, once equally filled by men and women, has come to be dominated by women. As a result, and because the archetypal dangdut singer in off-air practice is a woman, dangdut is

2 See Weintraub 2008 for an informative and insightful overview of the controversy surrounding Inul Daratista; compare Wallach 2014. The controversy is ongoing. 




FIGURE 1 Jus Geboy at his Bintang Pantura 5 audition

often considered to be a realm of power for women. These changing archetypes, as well as the circumstances of moral panic ${ }^{3}$ targeting LG BT bodies, have resulted in changing attitudes toward gender performance on dangdut television. In 2016, the Komisi Penyiaran Indonesia (K PI, Indonesian Broadcasting Commission) began to explicitly censor men who behave in a way termed effeminate (I. kewanitaan). ${ }^{4}$ Women singers have been censored, too-for immodesty, for

3 I use the term panic, as many other scholars and journalists have, to refer to the raids, protests, and proposed laws targeting perceived sexual immorality and sexual minorities. Religious groups and political parties created a sense of threat and fanned the flames with incendiary comments to create a sense of panic. This fervor peaked in 2016-2017; see Boellstorff 2016 and Davies 2016 for background information.

4 See discussion in footnote 15 . 
dances that are too erotic, and for crass humour - and yet no edicts exist policing their femininity. Masculinity is unevenly targeted.

When a man puts himself in the role of professional dangdut singer, a role usually taken by a woman, he creates a tenuous situation regarding his gender in the eyes of the public. Drawing on Judith Butler's idea of gender as performance, ${ }^{5} \mathrm{I}$ refer to this tenuousness as gendered danger, the danger that a man will not be able to perform as a satisfactory dangdut singer, as a sufficiently masculine public figure, and as a representative of a national music genre. This danger is gendered both because it concerns gender performance and because it disproportionately targets men. This is not to say that women singers face no censorship or discrimination based on their gender-on the contrary, proper masculinity is here defined in opposition to marked others, most often women and LGBT, the implication being that those others are inferior and shameful. However, the resulting range of properly gendered behaviour for male dangdut singers is narrow, and the stakes are high.

In his seminal history of dangdut, Andrew Weintraub writes of dangdut television: 'Dangdut tests the boundaries of what can be expressed and what stories can be told in the public sphere' (Weintraub 2010:114). Dangdut produces 'highly unstable meanings' with multiple possible interpretations, open for contestation or for a complete lack of interpretation. Dangdut is a realm of contestation; the Islamic moralism of star Rhoma Irama, the 'king' of dangdut, stands seemingly in contrast with the infamy of village concerts notorious for drunkenness and riots. For years, dangdut was banned on television, and the off-air practice thrived and developed its own norms and standards. At village concerts, almost all the singers are women, and their bodies and dancing form one of the main attractions. I use the term 'off-air' to distinguish between televised and non-televised dangdut performance, rather than the term 'live', as most dangdut television is broadcast live. Off-air and televised dangdut exist in dialogue with each other and are mutually constitutive. I argue that off-air performance shapes televised dangdut as much as the reverse, if not more. Fans generally consider televised dangdut to be only a shadow of off-air concerts.

However, in today's media-dense Indonesia, dangdut fans can watch, listen to, and even sing the music all day long through mass and social media. Dangdut-singing-competition television shows proliferated in the mid 200os, follow-

5 Susan Leigh Foster's (1998) argument that gender performance is more like choreography than improvisation may be of some import here, since choreography more clearly implies that a body is born into a world with a set of gendered steps already in place, which that body fails to imitate at its own peril. David Gere's (2001) work deals with masculinity as choreography in a similarly productive way. 
ing international reality television trends. Singing-competition shows attempt to reframe dangdut as a national art form appropriate for middle-class consumption.

Although women's bodies are synonymous with dangdut on concert stages, and women's modesty is certainly policed on television, men's behaviour has become a prominent target of television censors. Male dangdut singers on television are in an unusual position, as the very skills that have brought them success (a beautiful voice, compelling stage presence, fashion sense, dancing ability, and sharp humour) must be tempered to mesh with a sometimes elusive and undefined ideal of masculinity. To prove themselves cowokbanget, or super manly, men use Islamic and Arab symbols like dress, musical arrangement, and language; romance gimmicks with female co-stars on air and on social media; and pathos, especially demonstrating love for their mothers on air, as ways of declaring and performing masculinity and national citizenship. I argue that KPI attempts to mitigate gendered danger are based on a discursive foundation that grants bodies and actions power to cause irresistible responses-sometimes pleasurable, sometimes violent. I explore how the language of 'protection' - of children, but also of LG BT communities — gives rise to the censorship of gender expression. I ask what kinds of masculinity are allowed, acceptable, preferred, and dominant in dangdut television.

\section{Methods}

This article is based on sixteen months of ethnographic research in Indonesia, mainly in Java. ${ }^{6}$ I observed, and participated in, broadcasts at television and radio stations, both regional and national, in Surabaya and Jakarta, and interviewed producers, deejays, and television personalities. In addition, I interviewed fans, mainly based in Central and East Java. I also evaluated the media itself as a text, spending hours watching television-sometimes alone, sometimes with fans, additionally combining textual analysis with ethnographyand following the Instagram feeds of television stations and celebrities. My media analysis combines all these angles: my own analysis and responses, both backstage and in front of the television; the responses of fans; and the opinions and goals of producers.

6 This research was possible with support from a U.s. Fulbright Student Research Award, a grant from the American Institute for Indonesian Studies Department, and a Uc Riverside Graduate Research Mentoring Program Fellowhsip. 
Dangdut television is a small and very public world. For this reason, when I discuss data points drawn from ethnography or interviews, especially concerning LGBT issues, I write with anonymity in mind. Those I name are public figures, and I make no claim about their gender or sexuality beyond what they themselves have publically made.

\section{Dangdut Off-Air: Irresistible Bodies and Women's Power}

Despite the growing use of new media, dangdut is still most profitable for musicians outside the confines of television studios, and off-air dangdut events are extremely common. The most infamous dangdut performances take place along the highway that traces Java's north coast, nicknamed Jalan Pantura (the North Beach Highway). Stigmatized as overly erotic by middle-class Indonesians and foreign journalists alike, actual performances vary greatly, but there is a kernel of truth in the stereotypes. Along this road, women sing dangdutsometimes in nightclubs and brothels, sometimes at enormous wedding parties and club celebrations. In somewhat revealing clothing by Indonesian standards, women sing and dance and entertain a crowd, the majority of whom are men. These men dance together, closing their eyes. At rowdier performances, some drink alcohol and get into fist-fights. The music and beautiful women are irresistible, they say, and they must dance. They prepare money to hand directly to their favourite singers, who bend down to receive it in a tipping practice that predates dangdut, known as saweran, as shown in Figure 2.

In English-language scholarship, discussions of dangdut often turn to the question of exploitation, much as they do when discussing strip clubs and prostitution. ${ }^{7}$ The tradition of saweran and emplacement in nightclubs and brothels is probably partially responsible for that conflation. Some contexts of dangdut performance are indeed related to erotic labour. However, when I asked Indonesians about exploitation in dangdut, they usually assumed I was talking about women exploiting men. Women, they tended to argue, possess a great power inherent in their bodies. By simply revealing more of their bodies

7 See, for example, Ong and Peletz 1995, David 2003, and Browne 200o. Sandra Bader's (2012) dissertation about West Javanese and Sundanese dangdut tarling acknowledges that singers use the physical space of the stage and bodily empathy to negotiate positions beyond exploitation or empowerment. Weintraub (2008) similarly centres the power of women's bodies in his discussion of Inulmania. 


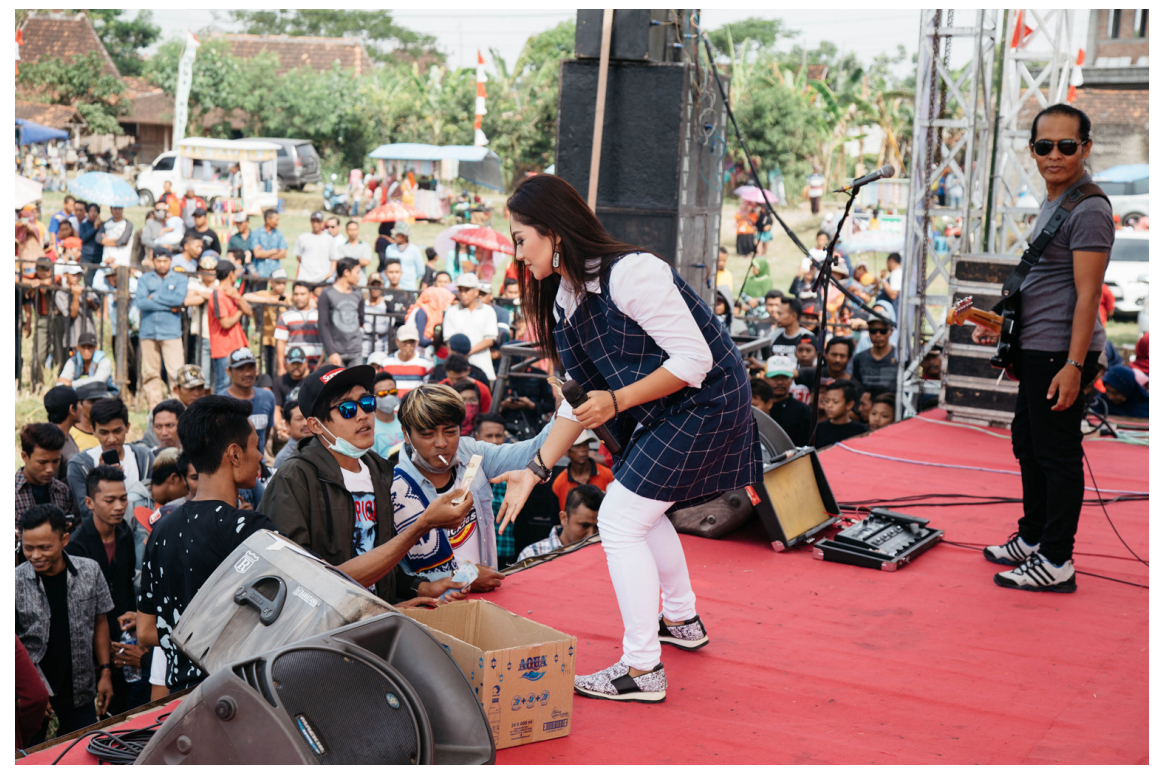

FIGURE 2 Singer Ratna Antika collects saweran from the audience, Pati, Central Java, July 2018

PHOTO BY THE AUTHOR

than is usual, or by dancing in an erotic manner, women move men to lose their senses, get carried away by their emotions, and give women money. ${ }^{8}$

This argument — and the assumed way in which it was usually presentedstruck me as relying upon completely different definitions of power and exploitation than I usually use. Some of the implied assumptions are clearly symptoms of patriarchy. The argument ignores larger gender and social-class dynamics in Java. For women of low socio-economic class without education, dangdut is one of only a few labour choices that offers the opportunity to advance. The argument also both assumes and reinforces harmful stereotypes of gender (men cannot control themselves; women must guard themselves, even when they are only doing their job) and class (low-class men are violent drunkards and behave like children). One could argue that this orientation is simply a tool men use to justify their actions, rather than a discursive foundation that anyone believes. However, these significant objections aside, the articulation of power and exploitation underlying this argument warrants closer attention, partly because it is not unique to dangdut.

8 Brenner (1995) points out that this same narrative may allow women to amass economic and social power, and may in fact serve as a discursive counterpoint to narratives about power and gender outlined by Anderson (1972) and Keeler (1990). 
In his landmark essay titled 'The idea of power in Javanese culture', Benedict Anderson outlines how concepts of power and political theory appear through the Javanese lens. He describes three facets of power in Javanese conception: power is concrete and homogenous; it is zero-sum, with only a set amount in the universe; and power 'does not raise the question of legitimacy' (Anderson 1972:8), meaning power is not categorized by source and the assigned value judgements based upon it. Power simply is, and Javanese political theory is based upon the accumulation of power. The ambitious can draw power to themselves through ascetic practices, which concentrate power around their person.

Similar ideas about spiritual potency in Java have been discussed by scholars like Ward Keeler (1990), Jane Atkinson and Shelly Errington (1990), and Suzanne Brenner (1995), for whom power's relationship to gender has been a central concern. Dangdut singers are hardly representative of the norm for gendered behaviour in Java. However, concepts of power and spiritual potency apply in interesting ways to dangdut performances. Singers, MCs, and even some instrumentalists are known for ascetic practices like fasting and going without sleep. A singer's success is determined not by her vocal skill, her creativity, or even her beauty but by an ephemeral ability to pull in crowds (I. tarik masa) - an idea reminiscent of Anderson's description of centralized power emanating from its source like a lightbulb. When dangdut fan clubs attempt to harm the reputation of another band or singer, they do so by citing evidence that a concert was poorly attended, thus calling into question their power. In this way, common belief grants dangdut singers a kind of power contained in their bodies, which emanates from them and controls the people and environment around them. This belief may have solidified precisely because it conveniently absolves men from their actions, but the fact remains that dangdut singers are discursively granted great power. For that reason, and because so few men become singers, many Indonesians consider dangdut to be a realm of feminine power. ${ }^{9}$

9 I consider dangdut to be a realm of women's power in other ways as well. Established dangdut singers form the focal point of families and communities, and their wages from performing provide economic security for the wider family and community group. Established dangdut singers are almost always savvy career women, not helpless victims. In addition, almost half of the managers of dangdut bands are women or are one half of a married couple that works together. 
Far from my research sites along Jalan Pantura, the television studios of Jakarta pump out episode after episode of dangdut television. On the Indosiar channel alone, dangdut takes up the prime-time slot from $6 \mathrm{pm}$ until midnight every night. Dangdut was not always accepted on television. Rhoma Irama, the father of classic dangdut, was banned from the national television station, TVRI, from 1977 to 1988, because it was thought the social ills addressed in his songs, like poverty and drunkenness, would destabilize audiences (see Hobart and Fox 2008). As dangdut increased in popularity and esteem, the government-run channels slowly recognized the potential dangdut held for both profit and satiating the masses. In the 199os, private television began to increase in visibility and make up a greater percentage of the market as both the economy and the power of consumers grew. These early shows took a variety of formats, from music videos to dangdut dramas to soap operas in which the characters would break out into dangdut songs to make their emotional point. Women singers, dressed in glamorous ballgowns, began to dominate the television stage. TPI, now called MNC or MNCTV, was the first channel to produce a dangdut singing-competition show in 2005, following in the steps of the newly popular television format (American idol began three years earlier, Pop idol four years earlier). In dangdut singing competitions, producers saw a new opportunity for boosting the prestige of dangdut among the middle class while still catering to the tastes of the majority. A singing-competition show must focus on singing, rather than on drumbeats or dance moves. They could bring dangdut out of the club, out of Pantura, and onto the national stage. However, aspects of the music and performance would have to be downplayed or changed to fit the television medium and middle-class tastes. Based on these factors, it is curious that it was during this period that women singers grew to dominate the televised dangdut stage. While my interviews with East Javanese singers indicate that women singers had a strong off-air presence, many mass media stars of the 198 os were men. Many factors might explain the rise of women on television. The changing gender dynamic on television reflected off-air changes, albeit with something of a delay. The increasing television viewership of female domestic workers, who may have idolized glamorous singers, might have contributed to this. This change in the balance of gender coincided with rising Islamic discourse in popular culture and attempts to make dangdut palatable to women and the middle class.

Because bringing dangdut to television makes public a performance that usually takes place in villages, clubs, or private homes, producers feel they must excise erotic performance from the music. The production team of Kontes 
dangdut Indonesia (KDI, Indonesian dangdut contest) explicates this line of thinking in their official statements of purpose, which includes the goal of promoting dangdut singers that have a 'different image' (I. citra berbeda) from other dangdut singers. ${ }^{10}$ Many producers I met echoed a similar sentiment. One producer at Radio Muara Jakarta said: 'Dangdut has huge potential to become popular internationally $[\ldots]$ but it must be done by different, higher-class dangdut singers with an international image."11 What exactly that 'different image' is, is never explicated by producers or government officials, but what the phrase implies is clear: the average dangdut singer has little formal education and a low socio-economic status, and her performance is decidedly erotic. A singer with a different image would have a refined singing technique, be of a higher social class, and have a more modest and polite bearing. She would be attractive without being erotic. Likewise, the practice of saweran to encourage eroticism must be removed. Cleansing the erotic from dangdut forms only one part of a broader strategy to make dangdut 'go international'.

Dangdut television explicitly attempts to represent the nation and spread dangdut abroad, as evidenced by the themes and mission statements of the various shows: $K D I$ 's theme proclaims 'a new class of dangdut', while the show Liga dangdut sports the theme 'arts unify us' (I. seni menyatukan). Dangdut Academy Asia hopes to promote dangdut in Southeast Asia. With explicit goals to produce and promote the nation, and with the KPI breathing down their necks, producers fret over the representation of the nation. In this context, they race to promote particular ideas of masculinity and sexuality on screen in the fear that what appears on screen may become the pattern on which the impressionable poor model their behaviour. By this logic, on one hand, the erotic power of women should be hidden and subjugated. On the other, to fill the power void left when the powerful women are removed, dangdut needs powerful men, masculine men, who can maintain control and who are above all else heterosexual. Televised dangdut thus bears little resemblance to off-air practice. What dangdut is - the essence of the genre-as well as who owns it, are constantly being contested to control the image of the nation and to maintain the 'proper' norms of gender and sexuality.

$10 \quad K D I$ official website (kdi.mnctv.com), accessed o4-08-2018.

11 'Dangdut itu mempunyai potensi besar buat mendunia [...] tetapi dangdut itu harus dibawakan penyanyi dangdut yang berbeda, yang berkelas dan citra international.' Personal communication with a producer at Radio Muara Jakarta, July 2018. 
Throughout Muslim Southeast Asia, rising tides of Islamic consumption have been manifesting in popular culture. As local Southeast Asian markets develop closer relationships with globalized Islam, many Southeast Asian Muslims have come to understand and perform their own religion differently. For creators of popular culture, the emerging power of Islamic consumption has altered their relationship with their performance and their religion. This is often especially true for women; Southeast Asia has long sustained diverse and dynamic women's singing traditions that must now interact with global Islamic pressures to conform to certain ideals of femininity, modesty, and moral virtue, ideals often based in the Middle East. For example, Bart Barendregt (2017) addresses how, in Malaysia, female Muslim pop stars face added gendered pressure to perform pious femininity on stage. In reference to pop star Princess Siti, he writes that the backlash against her duet with Sami Yusuf fell more heavily on the woman for failing to sufficiently preserve her modesty (Barendregt 2017:219).

In the Indonesian context, increasing access to globalized Islamic culture has occurred in tandem with democratization in the post-New Order Reformasi period. President Soeharto kept a tight lid on Muslim reformers. As Platt, Davies, and Bennett point out, democratic movements in the last twenty years in Indonesia have often worn an Islamic face. Reformasi, they argue, was 'born of moral crisis' and charged Soeharto and his family with corruption (Platt, Davies, and Bennett 2018:4). Many scholars, notably Carla Jones (2010a and b) and James Hoesterey (2016), have written about how women have been recentred as the primary targets of pious consumption campaigns in Indonesia-proper femininity and moral crisis have thus become two sides of one coin.

Global Islam and Indonesian modernities come into conflict with the potent force of the popular music genre dangdut. Although it is not usually categorized as Islamic music, in the sense that it is not used directly for worship of any kind and tends to be secular in lyrical content, as the most popular music of a majority Muslim country, dangdut is full of Islamic references and governed by Islamic standards. Although many performers and fans separate the realm of religion from that of entertainment, the rise of Islamic popular culture and moral panic coincides with the rise of dangdut's presence in the mass media, and the two co-exist with some tension. 
For several years, LG BT individuals, especially waria (trans-women) and effeminate men who were assumed to be gay (often referred to in the industry as banci), were visible on Indonesian television and considered a natural part of the industry, even if their sexuality was not explicitly accepted. Traditional folk and comedic theatre of many regions features effeminate men or transwomen, usually for comic effect. Not all trans-women functioned as punch lines, however; actress, singer, and TV personality Dorce Gamalama was well respected and had her own talk shows from 2005 until 2009 (see Murtagh 2017). Although Dorce certainly faced stigma, the rapid change-from a situation where an openly trans-woman had her own talk show at a major television station to a scenario in which all LGBT behaviour was being censoredseems significant and reflects changing attitudes towards LGBT in the public sphere.

Dorce Gamalama is an unusual case. More often, the danger for malepresenting LGBT individuals lies in overstepping the fine line between men who are considered charismatic and entertaining and men who are considered effeminate. This is especially true for men who work as hosts, presenters, or MCs on television. As one interviewee, a journalism student who identifies as gay, explained, 'being a banci, these days, it's more of a career path than a gender.'. ${ }^{2}$ The bright, bubbly, and quick character expected of a presenter is associated in the minds of many Indonesians with non-heteronormative gender and sexuality, perhaps because of theatre traditions like ludruk. Likwise, gender-bending and erotic humour is a staple of many Javanese arts. Men who pursue performing-arts career paths are thus often rewarded for behaviour considered effeminate. As Rey Aksara writes, in an editorial for the Indonesian feminist magazine Magdalene,

gay [behaviour] sells well—in addition to lowbrow entertainment-in Indonesia's TV shows. There is a slew of hosts who behave campily and engage in queer baiting through acts in which they display homoerotic tensions with their co-host or guest stars, only to be made fun of by the entire production crew and audience. The audience's ensuing hysterics actually unveils implicit homophobia.

AKSARA 2018

12 Personal communication, UNAIR Student, October 2019. 
I will return later to the questions of faking, visibility, and homophobia. Here, I emphasize that perceived effeminateness in men, regardless of whether it reflects their private gender and sexual identities, is popular in entertainment - until men become successful enough for the KPI to pay attention.

Rising moral panic found a target for outrage in 2016, when prominent dangdut singer Saiful Jamil (sometimes spelled Saipul Jamil) was arrested. His arrest was a catalyst for the tensions that already existed surrounding gender, sexuality, and the public sphere. His case was cut and dry to many Indonesians, since it involved an underage boy.

Saiful Jamil rose to fame with his dangdut boy band, called G4UL. ${ }^{13}$ After rising to popularity as a solo singer in the mid 2ooos, he married dangdut star Dewi Persik and became a jury member on the Indosiar dangdut contest Dangdut Academy.

On 18 February 2016, Saiful was arrested on suspicion of child abuse. He pleaded guilty and was sentenced to serve five to fifteen years in prison. Indosiar immediately cut ties with him. Although it is not written anywhere in the Tempo articles about the case, the 17-year-old that Saiful abused was a boy. That open secret-found only on certain gossip sites, but still commonly accepted as true ${ }^{14}$ - formed part of the impetus for the KPI regulation, along with the broader anti-LGBT panic occurring in Indonesia from 2016 to 2017 (Boellstorf 2016; Davies 2016).

The KPI was founded in 2002. The original intent of establishing it was to have an independent body manage broadcasting, in contrast with the earlier system, which was controlled and carried out by the national government. Along with new ownership, the KPI argued, they had new responsibilities toward the public interest. Following Saiful Jamil's arrest, the KPI published the following regulation:

The Central KPI through this letter asks you not to present men as hosts, talents, or other performers (both as the main and supporting cast) with the following features:

1. Women's manner of dress;

2. Women's make-up;

13 Roughly translated as 'slang', gaul can also indicate sociality, trendiness, or youthfulness.

14 Rumour and gossip feature heavily here, and their relationship to politics, government, witchcraft, and violence have been mentioned by scholars like Nils Bubandt (2006) and James T. Siegel (1998). Stewart and Strathern (2004) argue that rumour acts like a kind of witchcraft by 'projecting guilt on others in ways that may cause them harm'. In this case, the rumours circulate through gossip columns and social media posts. 
3. Women's body language (including but not limited to gait, sitting style, hand movements, or other behaviours);

4. Women's manner of speech;

5. Actions that justify or promote women's manner of behaviour for a man;

6. Using greetings or honorifics pertaining to women for men;

7. Using terms and phrases that are typically used among waria. ${ }^{15}$

The Central KPI considers these phenomena to be not in accordance with the provisions about respect for the norms of courtesy and decency that prevail in society for the protection of children and adolescents. Broadcasts containing such content might encourage children to learn inappropriate behaviour and/or consider it as normal in everyday life.

We will conduct intensive monitoring of all broadcasting institutions. We will impose sanctions if a broadcasting institution is seen to be broadcasting the above. [...] This is a circulation of the Central KPI and must be considered and obeyed. Thank you for your attention. ${ }^{16}$

The level of detail contained in the rules is staggering; rules against men sitting and using their hands like women, or using honorifics that pertain to women ${ }^{17}$ (although this still happens all the time, especially on local television). I am most taken aback by the embodied nature of what is said to constitute the promotion of false femininity. While the discussion and promotion of LGBT rights is clearly a sensitive topic, the commission focuses on the body, on movement and adornment.

Here the KPI's main justification includes, firstly, protecting children from learning alternative gender behaviour and, secondly, divergence from the pre-

15 Each of these statements uses the phrase kewanitaan or pria kewanitaan. In the case of pria kewanitaan, I have here used the word waria, as the language designates a specific group. In other cases, I have translated pria kewanitaan as a 'false woman' or an 'effeminate man', as the word indicates a being who is woman-like, but not truly a woman. The fraught linguistic terms, and the refusal of the KPI to use any of the more respectful or accurate terms available to them, like waria, transpuan, banci, or LGBT, merit their own analysis.

16 Translation by the author. The original circulation is provided in its entirety in the appendix.

17 Mistaken gender identity is the core of many 'gimmicks', or humorous interludes, used on dangdut television. While Indosiar and KDI no longer use this type of joke, regional shows like Stasiun dangdut still feature skits in which one of the presenters, a man who presents in an effeminate manner, dresses as a woman and pretends to be romantically interested in another male presenter. In these skits, the other presenters refer to the effeminate man by female honorifics like mbak (young woman) or ibu (mother or older woman). 
vailing societal norms. In Saiful Jamil's case, it is indeed relatively clear that the relationship was not condoned by legal standards (as the boy was underage). At the same time, underage marriage is common for girls in Indonesia. Homosexuality, rather than the boy being underage, was likely the driver behind the charges against Saiful.

However, the bylaws mentioned in the release tell a slightly different story. Of the three articles the KPI cites in its regulation to censor men who are effeminate (pria kewanitaan), the first simply reiterates the importance of respect for the norms of courtesy and decency that prevail in society. The second states: 'Broadcasting institutions must acknowledge and protect the rights and interests of: a. people and/or groups of workers that are deemed to be marginal; b. people and/or groups with a particular sexual orientation or gender identity.'18

This is seemingly the opposite of what is intended by their edict concerning men who are effeminate. The third section cited decrees that content rated $\mathrm{R}$ (for remaja, or teens) should not show content that encourages teens to learn about inappropriate behaviour or that considers inappropriate behaviour as normal. ${ }^{19}$

How does an organization that promises to acknowledge and protect the rights of persons regardless of gender or sexuality arrive at the conclusion that rendering this group invisible is the proper way to do so? One possible clue rests in other areas that are equally censored. For example, both the KPI and a similar organization for film censorship censor any material offensive to, or considered degrading towards, religions, ethnic groups, and races. This was famously demonstrated by the censorship of the film Tanda tanya (Question mark), which dealt with inter-faith tensions.

Here, the protection of rights does not extend to the right to presence in the public sphere. It does not include the right of expression. Rather, it seems to indicate that individual rights are superseded by the whole, and that if you do something to anger or offend the whole, violence will almost certainly be the outcome, a likely natural consequence. As a result, according to this world view, the best way to protect the rights of LG BT in Indonesia is to keep them hidden. Broadcast institutions protect the rights of marginalized groups by keeping

18 'Lembaga penyiaran wajib memperhatikan dan melindungi hak dan kepentingan:a. orang dan/atau kelompok pekerja yang dianggap marginal; b. orang dan/atau kelompok dengan orientasi seks dan identitas gender tertentu.'

19 See (4), 'Program siaran klasifikasi R dilarang menampilkan: a. muatan yang mendorong remaja belajar tentang perilaku yang tidak pantas dan/atau membenarkan perilaku yang tidak pantas tersebut sebagai hal yang lumrah dalam kehidupan sehari-hari.' 
them out of the conversation. To be safe, they must become invisible. This perception blames those who act in a way that sparks response from the majority. LGBT who insist on making their voices heard are seen as provocateurs, rather than as advocates for rights.

Anti-LG BT Sentiment and the Social Gaze

Ironically, given the way LG BT people are made invisible on screen, LGBT bodies are prominent in the dangdut world. Step backstage at any dangdut television show and you will meet a bevy of assistants and make-up designers who are openly LG BT, helping singers get ready and joking about their sexuality with strangers. In addition, many M C s and presenters are openly LG BT among fellow cast members, crew, and even producers. Openness backstage does not equate with openness on camera, however. Producers form the main point of mediation between performers and what is eventually broadcast. Although they do not openly express prejudice against their co-workers who are LGBT, the narratives and beliefs of dangdut singers and musicians themselves are often not the same as the values of producers and advertisers.

Television producers are usually university-educated and do not come to dangdut television as fans of dangdut; they are given an assignment and eventually grow to like the music. They espouse values that are often more explicitly based upon the principles of religion and morality (explicated as such). The television producers and radio hosts I interviewed in the course of my fieldwork tended to replicate a particular discursive framework. They said they have a responsibility (I. bertanggung jawab) to regulate, educate, and protect their audience-dangdut's fan base-from unsuitable influences. They see dangdut's fan base as in need of guidance (I. bimbingan). This is in keeping with the history of Indonesia's television industry, which, throughout the New Order, was either owned and operated directly by the government or by family members of those in power. To borrow Philip Kitley's phrase, television stations had clear paternalist aims (2000:77). Although the degree of paternalism varied throughout the New Order, it was common for information ministers to view the audience as childlike, not yet enlightened (I. masih bodoh), and in need of guidance and protection for the sake of development (I. pembangunan). This situation created a mixed mission that continues even in explicitly commercial television today among producers, who both view their audience paternalistically and obsessively check social media comments about the show in real time to gauge ratings and audience response for the sake of advertising sponsorships. 
Many producers of dangdut television believe it is their responsibility, given their superior education and understanding, to protect the lower class from the alternative understandings of gender and sexuality which are already present, even organic, among lower classes. From this viewpoint, which strikingly contrasts with that of many religious activists in Indonesia, gender and sexuality outside of the man/woman heteronormative dichotomy is not simply a Western import. Rather, it is a natural behaviour practised by the less civilized and more 'childlike' underclass, which needs to be shown alternative modes of behaviour, to be made civilized, and to be protected from alternative modes of being. Producers thus reproduce the moralizing sentiment shown by society more broadly.

At the same time, I do not believe that censorship of LGBT individuals is a deliberate aim of producers alone. Rather, it stems from the differing aims of a combination of industry actors, and is set against a backdrop of rhetoric common in Indonesian politics and beliefs about which words and behaviours are appropriate in the public, as opposed to private, sphere. As Philip Kitley writes, producers are only one set of all the actors with a vested interest in television production, who together create content in response to an imaginary audience they themselves construct. He writes: 'Institutions then endeavor to control this audience as a way of taking charge of their own survival' (Kitley 2000:74). While producers and regulatory boards likewise construct a childlike audience in need of guidance and education, their unique goals and positions create points of conflict. Producers of dangdut shows like Stasiun dangdut (JTV) and Bintang Pantura, who want to sell entertaining content and who work hand in hand with talent, view moral panic about LG BT and pornography with trepidation, even as they echo New Order rhetoric about the viewing public.

LGBT acceptance in dangdut television is thus situational, and behaviours and attitudes that seem accepting in some contexts (such as being openly LG BT backstage) do not necessarily translate to acceptance in places penetrated by the public gaze. The backlash against LG BT people on television is not necessarily caused by a hatred of LGBT individuals but, rather, by a fear that the nation will be represented —in this case, by television broadcasts across the globe-by gender behaviour that is considered weak or uncivilized. Underlying the censorship of dangdut television is the idea that dangdut is a national music genre, and that television in general does the work of representing Indonesia to outsiders and to its own citizenship. As long as a behaviour or way of being is not open to the social gaze, the risks to the nation are few.

Reactions to being LGBT in public relate to the discussion of powerful women's bodies above. When someone has a powerful emotional response, who 
is to blame for that response? What causes or creates that response? Just as the women dancing on stage are considered to have power over the men who dance beneath them, violence is a natural and expected response to other types of provocation. The behaviour of effeminate men on television may be one such type of provocation. In the case of LGBT behaviour, it is the very visibility of an act, body, or way of dressing that makes it dangerous, rather than its existence. As Tom Boellstorff writes of anti-gay violence in Jakarta in the early 200os, "[i]t appears that what is interpreted as "sexually provocative" or "gender-inappropriate" male behaviour leads to violence when it involves staking a claim to civil society' (Boellstorff 2004:476). Sharyn Davies Graham likewise notes that the inciting incidents of the anti-LG BT panics of 2016-2017 centred on visibility, such as when Minister of Technology, Research, and Higher Education Muhammed Nasir prohibited LGBT support groups on college campuses because they would increase LGBT visibility (Davies 2016).

In the case of dangdut television, the danger is that LG BT men will represent the nation abroad — and, therefore, also among its own citizens - through its popular music. As Rosalia Namsai Engchuan (this volume) writes in her contribution to this set of articles, 'the screen is imagined as the blueprint for the ideal Indonesian nation.' Boellstorff continues: 'In these cases, the entry of male homosexuality into public discourse is framed as motivating a gut-level reaction of malu, ${ }^{20}$ as if one's own (male) social self is threatened [...] This may be because the nation is perceived to be in imminent danger of being represented by non-normative men' (Boellstorff 2004:476). This gut-level reaction is as irresistible as the dancing woman's body or the sound of the drum; simply by being visible, a body might provoke a terrible act that could then be blamed on that body. The act of making oneself visible - whether the physical body or the sharing of a vulnerable experience-is enough to be accused of being provocative.

\section{Producing Acceptable Masculinity: Defending the Nation}

Men who sing dangdut occupy an ambiguous gender position: they are considered to be in the realm of women's power, and many of the men surrounding

20 Often translated as shame or embarrassment, malu holds the distinction of being among the most discussed words in the Indonesian language. For further discussion of malu, see Barker et al. 2014, Collins and Bahar 2000, and Lindquist 2004, among many others. 
them are assumed, if not openly known, to be gay. After the KPI edict, the need to successfully communicate one's masculinity in one's performance was of greater import. Some male singers are accepted automatically and are sufficiently masculine: being a member of the military and having children are both safe positions, as is a certain physical attitude and presence that is difficult to define. ${ }^{21}$ However, men who easily fit these categories are a rarity in dangdut television of the late 2010s. More commonly, men fall short of the ideal representation of the nation. Men who are seen as being effeminate, or who are termed overly dramatic or weak (I. lebay) in their performances by social media commenters, who possess feminine physical features, or who are differently abled make up a large percentage of the men who sing dangdut. Each must make the case that they are either sufficiently masculine or that they possess some other type of value that makes them a fitting idol for the nation. The most frequent performative strategies include Islamic or Arab spectacle, humour, heterosexual romantic gimmicks, and using stories about family and suffering to gain people's sympathy.

Within the toolkit of gendered behaviours that men who sing dangdut utilize to bolster the appearance of masculinity are symbols of Islamic piety. These include details of dress, music genre, and performance that reference either Islam itself or the Arab world more generally. Admittedly, during the holy fasting month of Ramadan and around other holy days, almost all dangdut musicians utilize some of these symbols in their performance and social media. Both men and women utilize these symbols to promote an image of piety or to give the impression they are showing their fans the details of their life off stage, which is in line with normative gender and Islam. However, men whose masculinity is in question choose to use these signifiers more frequently than the others. This is not a new phenomenon; Arab rhythms have been a part of dangdut since its earliest days, and male singers have emphasized their ties to the Arab world to demonstrate masculinity and cosmopolitanism. However, recent use of Arab tropes are significant, because the men deploying them are often those most in danger of being termed effeminate.

I want to clarify that these symbols do not necessarily reflect anything that is actually Islamic or Arab in nature. Rather, they reflect Indonesian concepts of Islam-ness and, in particular, Arabized Islam-ness. The clothing and singing styles they opt for may not have their roots in Islam at all, or may draw from

21 Henry Spiller's excellent book Erotic triangles (2010) discusses Sundanese masculinity with many references to Javanese masculinity. However, as is true in many cultures where masculinity is an 'unmarked' category, its essence defies easy description. 


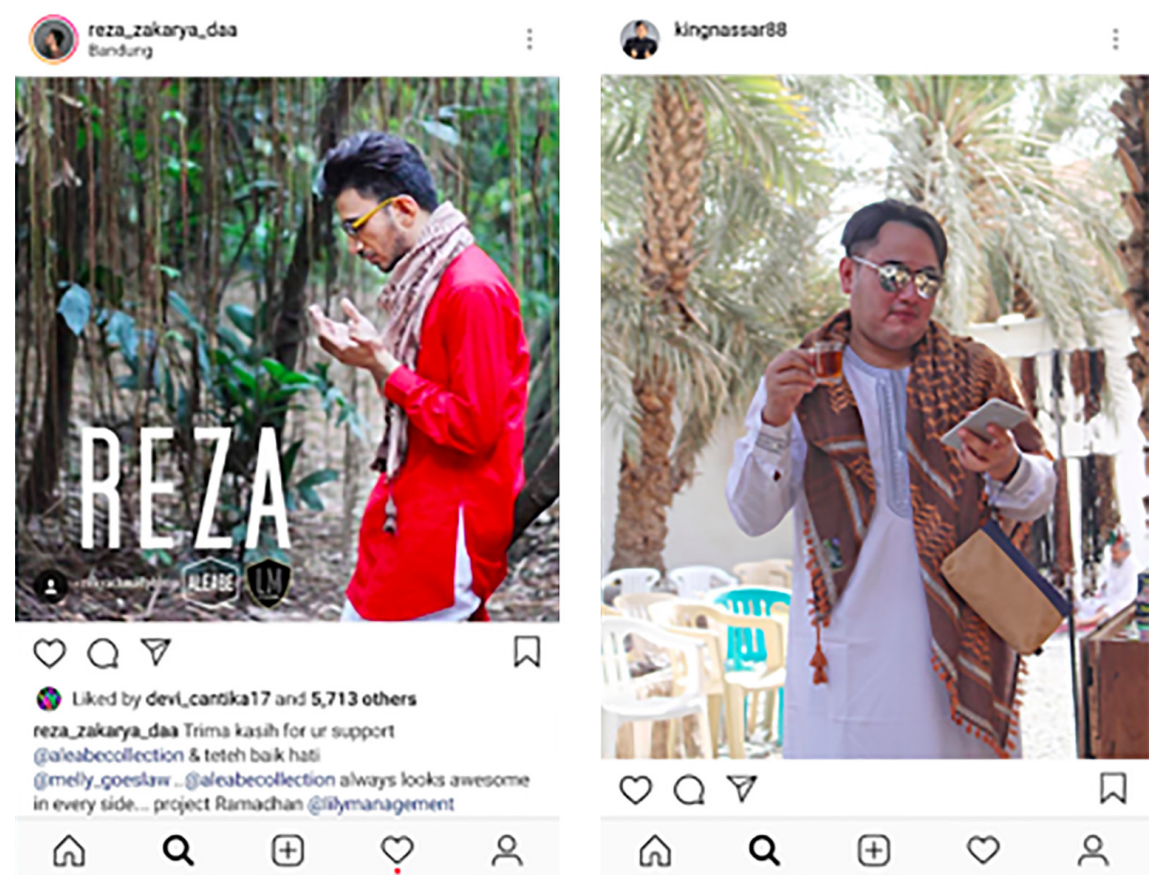

FIGURE 3 Reza (left) and Nassar post photos of themselves in scarves and tunics on their Instagram accounts.

localized Islamic practice; we are dealing with the realm of interpretation, the realm of symbol. These symbols, whatever the history of the object itself, are interpreted as Islamic in Indonesia, and emerge in the context of the spectacle of Islam in the public sphere. ${ }^{22}$

One straightforward example is clothing. Performers use pseudo-Arab or Indian styles to show piety and modesty. The most common styles used by men to show Islamic influence are scarves, often in a plaid, woven, Arab-style cloth; shirts with collars that button to the top and do not fold over; and long shirts in the style of thoub/thobe, dishdasha, or kandora, though in Java these rarely hang past the knees (see Figure 3).

Both singers attempt to maintain beards or a stubble. This is somewhat easier for Reza, who, it is rumoured, actually has Middle Eastern forebears (spreading this rumour may be another deliberate way to bolster masculinity, although many people in Indonesia are of partial Middle Eastern descent). Long cloaks or capes are also often interpreted as being Islamic in nature 
among dangdut fans, because of the uniform of Rhoma Irama, 'the king of dangdut', who post-hajj frequently wore long capes on stage and sung lyrics that taught Islamic values.

Headwear is one of the most potent symbols of Islam and sends a very direct message when used by both men and women. In Java, headwear can demonstrate adherence to particular Islamic organizations. However, in the dangdut industry, men most commonly wear Arab-influenced headwear when they want to signal their piety or their musical lineage.

This brings us to another way of signalling: singing style and technique. Technique that is more Islami or Melayu is more often interpreted as masculine, or at least serves as a counter to non-masculine symbols. The ability to smoothly and easily perform cengkok, or melisma, can signal a pious upbringing and skills in Quranic recitation for both men and women, especially if the cengkok have what is referred to as a Melayu or Arab flavour to them. Fans told me Reza and Nassar both have an 'Arab' sound to their singing. Jus Geboy, on the other hand, employs a 'pop'-like dangdut Pantura technique, which lacks any such Islamic connotations.

Language and genre function as symbols in much the same way. One of the main techniques of masculinizing performance through the inclusion of Islamic influence is singing qasidah, an Arab-influenced song genre sung in Arabic. Singing in the Arabic language in general indicates piety, as it demonstrates a religious education. In addition, they might use Arabic terms of address or expressions to signal Islamic piety. As national channels, Indosiar and MNCTV both use the national language Indonesian as the primary language. However, using an Islamic greeting or expression can signal piety and humility for contestants of all genders and increase their fan base. Yet the fact remains that men, far more than women, sing in Arabic on dangdut television.

Nassar and Reza demonstrate a wider pattern in contemporary dangdut television connecting Islamic symbols and issues of gender and sexuality. First, it is indeed men who are less masculine who use these symbols most. Nassar perhaps has the most to lose, as a close friend of Saiful Jamil, who similarly went through a messy, public divorce. Islamic signifiers are mainly employed by those whose masculinity is seen to be in question. For example, Ridwan, a contestant from Liga dangdut with a military background, was repeatedly called cowok banget - or super manly_ by jury member Inul Daratista throughout the course of the show. He never bothered to use Islamic signifiers, and his masculinity was never questioned by my interlocutors. This compliment, cowok banget, bolstered public opinion of his performance, even when his singing technique was not as polished as the other contestants. 
Second, men on the peripheries of masculinity use techniques other than Islamic symbols to bolster public perception of their masculinity. Nassar in particular shows as much evidence of dating women as possible on his social media accounts, and Indosiar writes romantic jokes and interludes with women into the show for him. His recurring fake romances and the Instagram commenters who encourage them, asking when he will find his true love, or recommending one of the women on the show as his soul mate, indicate that perhaps the palpable danger of homosexual behaviour risks something larger than Nassar's personal happiness.

Thirdly, female dangdut singers who use Islamic symbols do not do so to enhance their perceived femininity, apart from using Arabic expressions to appear humble. Head coverings like the hijab are the most religiously loaded symbols for women singers. Female dangdut singers frequently don the hijab temporarily and situationally. For example, if booked for an Islamic event, or during the month of Ramadan, or when engaging in religious tourism, they will wear a hijab and post photos of themselves in it on social media. Some even wear the hijab in their private lives and take it off for their performances, following what they deem to be the requirements of dangdut performance. ${ }^{23}$ They cite a variety of reasons for doing so, from guarding against sexual harassment to participating in hijabi fashion trends. Outside of the dangdut industry, Indonesian women are often told that they look prettier and more feminine with the hijab. However, within the dangdut industry, and especially on dangdut television, I have never seen evidence of a singer being considered more feminine, or more properly enacting her gender, because she wears the hijab. On the contrary, women's bodies are considered to be their greatest power. During off-air concert performances, women's bodies give them irresistible power over their audiences. On television, this power is dulled somewhat by favouring young women who project an air of childlike, feminine innocence; Islamic symbols like singing in Arabic and wearing the hijab are still noticeably absent, however, from this construction of femininity. Fans who comment on social

23 It must be noted here that a subgenre of dangdut which mixes dangdut and qasidah, or religious song, features women singers who almost always wear a head covering. This subgenre is increasing in visibility and popularity. Bands like Qasimah and musicians like Mutik Nida blend qasidah and dangdut because it allows them the freedom to perform, tour, and even play instruments with minimal damage to their reputations. However, for young, female dangdut singers, wearing an Islamic head covering during performances outside of religious holidays still relegates them to niche genres, performance contexts, and stage personas. 

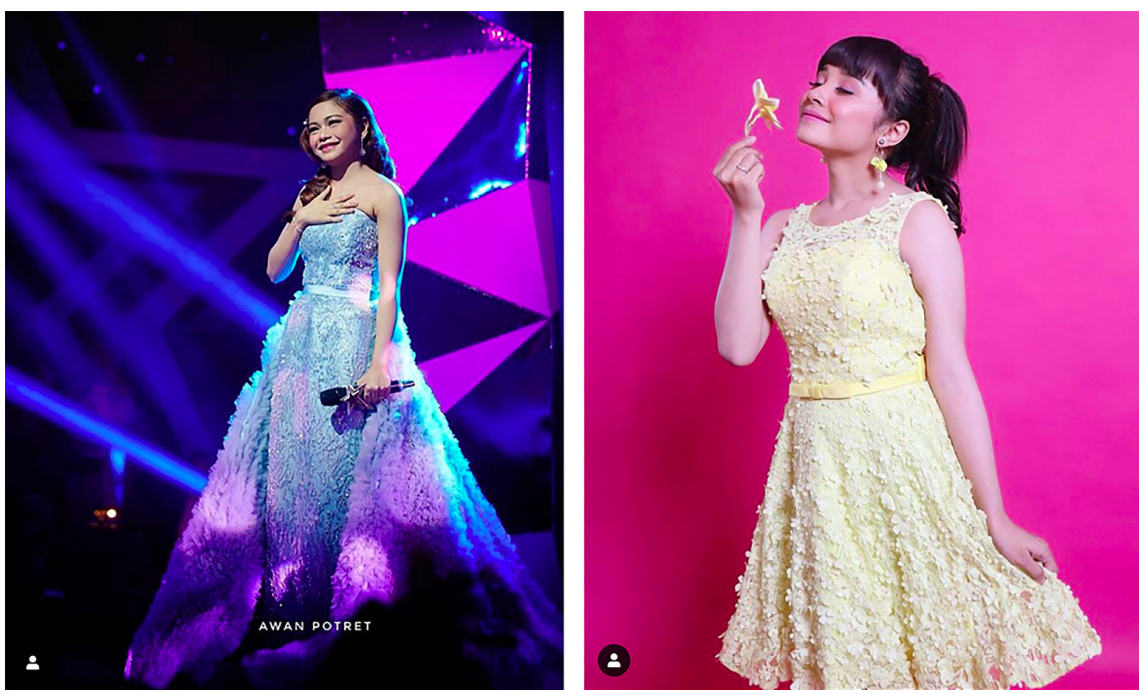

FIGURE 4 Rara (left, photo used courtesy of Awan Potret) and Tasya Rosmala are currently the models of femininity in the dangdut industry.

media usually name women who are young, slim, pretty, and do not wear the hijab, like Tasya Rosmala and Rara, not only as the most desirable but also as the most feminine, delicate, and sympathetic in their performance (see Figure 4). In contrast, jury members who wear the hijab and use Arabic cengkok are mature, established singers. This contrast highlights the double standard in dangdut television.

Islam is not the only signifier of masculinity utilized by those on the brink of failure to perform gender, but it does seem to hold particular significance. Nassar tries with all his might to tap into the Islamic signifiers and has, thus far, managed to keep his position and avoid censure. But those who completely fail, like Jus Geboy, often completely lack those signifiers. The jury loved Jus Geboy. I had rarely seen them laugh so hard or look so impressed. But when comedian and singer Soimah, who served as moderator for the show, asked the jury members, point blank, why none of them chose Jus Geboy, no one knew how to answer. They could laugh at Jus Geboy, but explaining why they were laughing - and why that laughter meant he could not be a contestant on the show-would be stepping into forbidden territory according to the KPI, public opinion, or both.

If Islam fails as a tool to create a masculine image, many men turn to more direct means. On air, both Reza and Nassar engage in flirtation and romantic gimmicks with their female co-stars. These gimmicks are hugely successful on social media, where fans weigh in on their relative favourite pairings. These 
produced-for-television romances never bear fruit, but they do allow stars to obscure perceptions of their gender and sexuality, which I will discuss further later.

Humour is another tool that men at risk use to make their performance more appealing. Like presenters, male singers who present in an effeminate way are expected to be funny. Nassar relies heavily on humour to make the case that he is both a skilled entertainer and a worthy representative of Indonesian popular culture. Like the humour presenters use, Nassar's jokes sometimes approach eroticism, as when, during the third season of Dangdut Academy Asia, he had a twerking competition with Thai contestant Jirayut. The other jury members collapsed with laughter as the two men, standing next to each other, gyrated their hips in time with the music. Unlike with Arab symbols, fans did not tell me that humour made the men appear more masculine; however, they more readily accepted effeminateness if it fulfilled the stereotypes associated with the banci character.

Some men are left out of the discourse of masculinity entirely. Men who are differently abled in particular fight an uphill battle. Arif, a contestant from season one of Liga dangdut who is blind, received third place in the competition. Blind performers are common on Indonesian television, as a stereotype holds that singing is a suitable profession for them. Arif was never accepted by the judges or fans as either funny or romantic, and so he relied upon a beautiful voice, Islamic symbols, and pathos. More than once, his mother was invited to the stage to describe the trouble and sacrifice it took to raise him. Jury members wept over their struggles. As condescending as the performative pathos seemed to me as a viewer, it was effective for a time in creating a strong fan base for Arif. However, when it seemed as though Arif might win the whole competition, the judges went against the popular vote to block him from the final, relegating him to third place. Arif was rejected as a representative of the nation.

Dangdut Celebrity and Piety Plays: The aspal

Carla Jones (2010b:618), writing about pious consumption, says: 'representations traffic in faith in ways that generate the conditions for their own potential critique, raising the spectre of illusion, concealment, or deception, what Webb Keane (2007) has called "insincerity"'. Here I do not wish to accuse Nassar, Reza, or any other dangdut singer or being insincere or falsely Islamic. Nor did I encounter many accusations of insincerity directed toward performers. In my ongoing research among women dangdut singers, I see every day the multi- 
interpretational approach to Islam that allows women to work in clubs at night and pray at the mosque in the morning without a thought about hypocrisy. Nor do I intend to debate the position of LGBT rights within Islam.

I do, however, want to delve into the question of illusion, sincerity, and authenticity in representation. Perhaps the most striking thing about interviews surrounding dangdut competition shows is that, when asked directly about Nassar, most people acknowledged his effeminateness, if not his sexuality, with a little laugh or surprised glance, if not directly verbally. Nassar's masculinizing attempts do not succeed to the point that laypeople believe them. This brings up an intriguing question: what happens when these representations are known by all to be false, or at least to not be the whole story, even by the target of the representation? That is to say, what does it mean that Indosiar promotes extended gimmicks playing on Nassar's heterosexuality to an audience that does not believe in that heterosexuality? Like dangdut itself, with its powerful blend of mournful lyrics and a drumbeat that pushes one to dance, this representation creates a situation that celebrates the possibility for vague and multiple interpretations. On air, these shows sometimes skirt around the edges of explicating LGBT orientations, but stop short of verbalization. Once LGBT phenomena are verbalized, they are no longer deniable, and all that matters to the KPI is that they are deniable. This double-speak is not insincerity, nor can it simply be called subversion. It is rooted in the desire to please, a high tolerance for nuance, and local understandings of what is entertaining, rather than in either activism or LGBT caricature.

Various scholars in Indonesian studies have already explored sincerity and authenticity as it applies to religion. Jones (2010a and 2010b) and Hoesterey $(2016,2017)$ both draw on the Indonesian colloquialism aspal in their discussions of public representations of piety. First explored by Siegel (1998), aspal combines the words asli (real or original) and palsu (false or counterfeit) to mean 'the falsely real', or 'the almost authentic'. Siegel's discussion centres on the material: knock-off shoes, forged bills and divorce documents, dukun who fail to deliver on their promises. The almost authentic nature of items or powers is determined by their success in performing as expected, not in their origin or process. ${ }^{24}$ When the shoes break down, or the divorce documents are revealed

24 This discussion makes reference to the 1990 film Paris is burning (Livingston 1990) and Judith Butler's commentary Gender is burning, in which she refers to all gender as 'drag' (Butler 1993:338), arguments she later expanded in Gender trouble (Butler 1999). Aspal here relates to the concept of 'realness', which is defined in Paris is burning as 'to look as much as possible like your straight counterpart' but to do so in the context of drag balls, where everyone knows the representation is false. 
to be false, that revelation, their failure to perform, is what makes them false. Siegel writes of a dukun who promised to create money using magic that it is not the technique that makes it palsu; as long as he is successful, magic is as effective as any other method for creating money. As Siegel (1998:59) phrases it: 'He becomes palsu when it becomes clear that he has not performed the way he should (and might) have.' Men who sing dangdut and attempt to hide their LGBT identity might be described in the same way. Saiful Jamil became palsu only when his LG BT behaviour was clearly revealed. James Peacock comes to a similar conclusion about waria performance in ludruk. Waria singer roles were the most refined (Jv. alus) in manner and appearance. He writes: '“alusness" is in part itself the essence of façade - the spiritual, unreal, the attitude that momentary appearance is what counts' (1968:212).

Scholars like Jones and Hoesterey who discuss aspal do so mainly in the context of religious figures, companies, and products. As an increase in political and consumptive Islam intersects with new media, anxieties about authenticity follow. The proliferation of scandals centred on pious figures demonstrate the stakes. Hoesterey points out the pleasure with which netizens take down those who portray themselves as pious. Accusations of hypocrisy are damning for public figures who make careers out of building an empire of piety, as in the cases of Aa Gym (Hoesterey 2016) and Tifatul Sembiring (Hoesterey 2017). Dangdut television presents a tantalizing contrast to the power of accusations of insincerity. In the case of male dangdut singers, plays at Islamic piety and heteronormativity are widely read as being exactly that: plays. And yet, for the audience at large, those plays seem to be satisfying — not because they accurately represent the public figures' inner life, but because the play exists. The play itself makes deniable any rumours of non-normative behaviour.

Why does the reaction to dangdut singers differ from reactions to clerics, Islamist political parties, and explicitly Islamic television personalities? Part of the issue may be that the degree of hypocrisy audiences detect depends upon the realm of the action and the degree of the claim. When I asked fans about whether dangdut singers could be held up as models of correct religious behaviour, a large percentage incredulously replied that, just like other people, there are dangdut singers who are good and singers who are less good. Many pointed out that dangdut is the realm of entertainment (hiburan) and so the question of religious piety simply does not apply — a response that surprised me given the public debates over pornography and singers' bodies. If they publicly play at heteronormativity and piety, the private lives of singers are innocent until proven guilty. Siegel (1998:57) himself echoes this argument: 'Hypocrisy is concerned with the difference between origin and expression. That is not exactly the interest in the palsu, a word taken not from Indonesian but from the Eng- 
lish false, whose sense as it is used seems to me to be as much "almost valid" as it is "counterfeit". In the Indonesian press, what works is valid.'

\section{Hidden for Their Protection: Deniable Bodies}

In dangdut television, the stakes of representing the nation as heteronormative and modern collide with a fear of power: the power of women's bodies and the power of provocation caused by the danger of the nation being represented by effeminate men. These fears reveal themselves in the KPI's regulations for dress and behaviour in keeping with stereotypical gender norms. Thus, part of the justification for censoring the bodies of men who are too feminine in manner, dress, or behaviour is to prevent the kind of outburst of anger that would lead to violence. Men use symbols of Islam as a strategy —one of severalfor displaying masculinity. These piety plays are widely accepted as sufficient to cover non-normative gender behaviour, provided nothing that should be private comes to light.

This analysis could be interpreted as an almost hopeful perspective on LG BT rights in the media, celebrating that long-lauded tolerance for diversity and love of nuance shown by Indonesians in general. Although visions of 'proper' masculinity and femininity have long been promoted by the state and by certain other class and religious apparatuses, they are by no means universal or equally absorbed across region, religion, ethnic/language group, or gender. The flexibility of off-air dangdut, which serves as a liminal space in which eroticism and pleasure are celebrated rather than censored, sometimes bleeds over into the television practice of dangdut. Dangdut fans often resist the opinions of political parties or governments. A deep layer of cynicism underlies their relationship with official power structures, a cynicism that results in a kind of double-speak, or even double-thought, for what kind of behaviour is acceptable contextually.

Scholars should thus resist the assumption that a performer like Nassar is necessarily suffering because of his position. As Davies (2016) writes, 'invisibility has provided many LGBT people in Indonesia with some sanctuary'-a sanctuary I would not deny them. Performed piety may likewise provide sanctuary. As Jones (2010b) points out, piety deliberately displayed is not by necessity free from affect. An adherent can feel deep devotion in the process of displaying piety. Dangdut singers drawing from Islamic and Arabic idioms likely feel deeply the spiritual significance of the music, the words, and the clothing on which they draw. The use of Islamic signifiers in dangdut does not point to insincerity forced by the situation; rather, it points to resilience and agency 
in the fashioning of the self among men who feel their gender performance is at risk of damaging their career aspirations. Likewise, silence and invisibility are frequent responses to social conflict and danger. As Sari Andajani-Sutjahjo, Linda Rae Bennett and Sharyn Graham Davies (2018) write of sexual violence against Chinese Indonesians in 1998: 'Silence can be an expression of agency over one's life, a display of rights and individual sovereignty. Silence can represent one's ability to escape formation and surveillance and exist elsewhere, beyond the order of law.'

At the same time, becoming invisible may not be enough to protect LGBT people in Indonesia and may in fact contribute to the ongoing panic. AndajaniSutjahjo, Bennett and Davies acknowledge that the strategies of using silence to subordinate others and staying silent to display power or escape the law are not mutually exclusive. Moral panic relies on the idea that LGBT status is hidden, that it can spread like a disease and infect anyone, even perhaps without their knowledge. This rhetoric echoes the New Order's use of the idea of hidden or shapeless organizations (I. organisasi tanpa bentuk) to justify the killing and incarceration of suspected communists. It remains to be seen whether invisibility as a strategy — and the performances of piety often involved — can protect the lives and careers of Indonesian dangdut performers.

I have connected recent censorship of effeminate men on Indonesian television to the concepts of power and provocation usually applied to women's bodies. In this conception of power, just as female dangdut singers can irresistibly attract audiences, visible LG в bodies likewise possess the power to cause violent responses. The solution for LG B T bodies is to become invisible for their own safety - to be seen but not seen. In dangdut television, the gender performance of male singers is scrutinized. To counter the danger to their careers, and even their freedom, men use symbols of Islam and the Arab world to influence perceptions of their masculinity. This display of piety satisfies the audiences and censors, and, until a rupture in the fabric throws the performance into doubt, everyone returns to enjoying the music.

\section{References}

Aksara, Rey (2018). 'Being gay and Indonesian: Appropriated but marginalized', Magdalene Indonesia, 5 February. https://magdalene.co/story/being-gay-and-indonesian -appropriated-but-marginalized.

Andajani-Sutjahjo, Sari, Linda Rae Bennett and Sharyn Graham Davies (2018). 'Silent strategies: The legacy of sexual violence among Chinese Indonesians', Intersections: Gender and Sexuality in Asia and the Pacific 42 (August) online. 
Anderson, Benedict (1972). 'The idea of power in Javanese culture', in: Claire Holt (ed.), Culture and politics in Indonesia, pp. 1-70. Ithaca, NY: Cornell University Press.

Atkinson, Jane and Shelly Errington (eds) (1990). Power and difference: Gender in Island Southeast Asia. 1st edn. Stanford, cA: Stanford University Press.

Bader, Sandra (2012). 'Intersubjective realities: Women dangdut performers and their lived experience in Indramayu and Jakarta, Indonesia', Melbourne, Australia: Monash University. https://doi.org/10.4225/o3/58a67ca40371b.

Barendregt, Bart A. (2017). 'Princess Siti and the particularities of post-Islamist pop', in: Andrew N. Weintraub and Bart A. Barendregt (eds), Vamping the stage: Female voices of Asian modernities, pp. 211-33. Honolulu: University of Hawai'i Press.

Barker, Joshua, Erik Harms, and Johan Lindquist, eds. (2014). Figures of Southeast Asian modernity. Honolulu: University of Hawai'i Press. http://site.ebrary.com/lib/ucr/Doc ?id=10745620.

Boellstorff, Tom (2004). 'The emergence of political homophobia in Indonesia: Masculinity and national belonging', Ethnos 69-4:465-86. https://doi.org/10.1080/oo1418 4042000302308.

Boellstorff, Tom (2016). 'Against state straightism: Five principles for including LGBT Indonesians', E-International Relations (blog), 21 March. https://www.e-ir.info/2016/ o3/21/against-state-straightism-five-principles-for-including-lgbt-indonesians/.

Brenner, Suzanne April (1995). 'Why women rule the roost: Rethinking Javanese ideologies of gender and self-control', in: Aihwa Ong and Michael G. Peletz (eds), Bewitching women, pious men: Gender and body politics in Southeast Asia, pp.19-5o. Berkeley: University of California Press.

Browne, Susan J. (2000). The gender implications of dangdut kampungan: Indonesian 'low class' popular music. Clayton, Victoria: Monash University, Centre of Southeast Asian Studies.

Bubandt, Nils (2006). 'Sorcery, corruption, and the dangers of democracy in Indonesia', The Journal of the Royal Anthropological Institute 12-2:413-31.

Butler, Judith (1990). Gender trouble: Feminism and the subversion of identity. New York: Routledge. [Thinking Gender.]

Butler, Judith (1993). Bodies that matter: On the discursive limits of 'sex'. New York: Routledge.

Collins, Elizabeth Fuller and Ernaldi Bahar (2000). 'To know shame: Malu and its uses in Malay societies', Crossroads: An Interdisciplinary Journal of Southeast Asian Studies 14 (1): $35^{-69}$.

David, Bettina (2003). The erotics of loss: Some remarks on the pleasure of dancing to sad 'dangdut' songs. Leiden: KITLV.

Davies, Sharyn Graham (2016). 'Indonesian "tolerance” under strain as anti-LGBT Furore Grows', Asian Studies Association of Australia (2o March). http://asaa.asn.au/ indonesian-tolerance-under-strain-as-anti-lgbt-furore-grows/. 
Foster, Susan Leigh (1998). 'Choreographies of gender', Signs 24-1:1-33.

Gere, David (2001). '29 effeminate gestures: Choreographer Joe Goode and the heroism of effeminacy', in Dancing Desires: Choreographing sexualities on and off the stage, pp. 349-81. Durham, North Carolina: Duke University Press.

Hobart, Mark and Richard Fox (2008). Entertainment media in Indonesia. London: Routledge.

Hoesterey, James Bourk (2016). Rebranding Islam: Piety, prosperity, and a self-help guru. Stanford, CA: Stanford University Press. [Studies of the Walter H. Shorenstein AsiaPacific Research Centre.]

Hoesterey, James B. (2017). 'Sincerity and scandal: The cultural politics of "fake piety" in Indonesia', American Ethnological Society (8 November). https://americanethnologi st.org/features/collections/piety-celebrity-sociality/sincerity-and-scandal.

Jones, Carla (2010a). 'Images of desire: Creating virtue and value in an Indonesian Islamic lifestyle magazine', Journal of Middle East Women's Studies 6-3:91-117. https:// doi.org/10.2979/mew.2010.6.3.91.

Jones, Carla (2010b). 'Materializing piety: Gendered anxieties about faithful consumption in contemporary urban Indonesia', American Ethnologist 37-4:617-37. https:// doi.org/10.1111/j.1548-1425.2010.01275.x.

Keeler, Ward (1990). 'Speaking of gender in Java', in: Jane Monnig Atkinson and Shelly Errington (eds), Power and Difference: Gender in Island Southeast Asia, pp. 127-52. Stanford, CA: Stanford University Press.

Kitley, Philip (2000). Television, nation, and culture in Indonesia. Athens, оH: Ohio University Center for International Studies. [Research in International Studies, Southeast Asia Series 104.]

Lindquist, Johan (2004). 'Veils and ecstasy: Negotiating shame in the Indonesian borderlands', Ethnos 69 (4): 487-508. https://doi.org/10.108o/o014184042000302317.

Livingston, Jennie (199o). 'Paris is burning', IMDb. http://www.imdb.com/title/tto1oo 332/ (accessed 17 April 2019).

Murtagh, Ben (2017). 'Double identities in Dorce's comedies: Negotiating gender and class in New Order Indonesian cinema', Bijdragen Tot de Taal-, Land- en Volkenkunde 173-2/3:181-207.

Ong, Aihwa and Michael G. Peletz (eds) (1995). Bewitching women, pious men: Gender and body politics in Southeast Asia. Berkeley: University of California Press.

Peacock, James L. (1968). Rites of modernization: Symbolic and social aspects of Indonesian proletarian drama. Chicago: University of Chicago Press. [Symbolic Anthropology.]

Platt, Maria, Sharyn Graham Davies, and Linda Rae Bennett (2018). 'Contestations of gender, sexuality and morality in contemporary Indonesia', Asian Studies Review 421:1-15. https://doi.org/10.108o/10357823.2017.1409698.

Siegel, James T. (1998). A new criminal type in Jakarta: Counter-revolution today. Durham, NC: Duke University Press. 
Spiller, Henry (2010). Erotic triangles: Sundanese dance and masculinity in West Java. Chicago and London: University of Chicago Press.

Stewart, Pamela J. and Andrew Strathern (2004). Witchcraft, sorcery, rumors, and gossip. Cambridge, Uk: Cambridge University Press. [New Departures in Anthropology.]

Wallach, Jeremy (2014). 'Notes on dangdut music, popular nationalism, and Indonesian Islam', in: Barendregt, Bart (ed), Sonic modernities in the Malay world: A history of popular music, social distinction and novel lifestyles (1930s-200os), pp. 271-89. Leiden: Brill.

Weintraub, Andrew N. (2008). “"Dance drills, faith spills”: Islam, body politics, and popular music in post-Suharto Indonesia', Popular Music 27-3:367-92.

Weintraub, Andrew N. (2010). Dangdut stories: A social and musical history of Indonesia's most popular music. Oxford: Oxford University Press.

Weintraub, Andrew N. (ed.) (2011). Islam and popular culture in Indonesia and Malaysia. Abingdon, Oxon and New York: Routledge. [Media, Culture and Social Change in Asia 24.] 


\section{Appendix I: Circulation to All Broadcasting Institutions Concerning Men Who Are Kewanitaan (Full Text)}

TABLE 1 Edaran kepada Seluruh Lembaga Penyiaran Mengenai Pria yang Kewanitaan

\begin{tabular}{|c|c|}
\hline Tgl Surat & 23 Februari 2016 \\
\hline No. Surat & /K/KPI/O2/16 \\
\hline Status & Edaran \\
\hline Stasiun TV & Seluruh Lembaga Penyiaran \\
\hline Program Siaran & Mengenai Pria yang Kewanitaan \\
\hline $\begin{array}{l}\text { Deskripsi } \\
\text { Pelanggaran }\end{array}$ & $\begin{array}{l}\text { Komisi Penyiaran Indonesia Pusat (KPI Pusat) berdasarkan wewen- } \\
\text { ang, tugas dan kewajiban yang diatur dalam Undang-Undang } \\
\text { No. } 32 \text { Tahun } 2002 \text { tentang Penyiaran (UU Penyiaran), berwenang } \\
\text { untuk mengawasi pelaksanaan peraturan dan Pedoman Perilaku } \\
\text { Penyiaran serta Standar Program Siaran ( } \mathrm{P}_{3} \text { dan SPS) KPI Tahun } \\
2012 \text { serta menampung, meneliti dan menindaklanjuti aduan } \\
\text { masyarakat. }\end{array}$ \\
\hline
\end{tabular}

Berdasarkan hasil pemantauan dan aduan yang kami terima, terdapat program siaran yang masih menampilkan pria yang berperilaku dan berpakaian seperti wanita. Sesungguhnya KPI Pusat telah melarang muatan tersebut melalui beberapa surat edaran yang dikeluarkan. KPI Pusat melalui surat ini meminta saudara/i untuk tidak menampilkan pria sebagai pembawa acara (host), talent, maupun pengisi acara lainnya (baik pemeran utama maupun pendukung) dengan tampilan sebagai berikut:

1. Gaya berpakaian kewanitaan;

2. Riasan (make up) kewanitaan;

3. Bahasa tubuh kewanitaan, (termasuk namun tidak terbatas pada gaya berjalan, gaya duduk, gerakan tangan, maupun perilaku lainnya);

4. Gaya bicara kewanitaan;

5. Menampilkan pembenaran atau promosi seorang pria untuk berperilaku kewanitaan;

6. Menampilkan sapaan terhadap pria dengan sebutan yang seharusnya diperuntukkan bagi wanita;

7. Menampilkan istilah dan ungkapan khas yang sering dipergunakan kalangan pria kewanitaan. 
TABLE 1 Edaran kepada Seluruh Lembaga Penyiaran (cont.)

KPI Pusat menilai hal-hal tersebut tidak sesuai dengan ketentuan penghormatan terhadap norma kesopanan dan kesusilaan yang berlaku dalam masyarakat serta perlindungan anak-anak dan remaja. Siaran dengan muatan demikian dapat mendorong anak untuk belajar dan/atau membenarkan perilaku tidak pantas tersebut sebagai hal yang lumrah dalam kehidupan sehari-hari.

Hal tersebut sebagaimana diatur dalam Standar Program Siaran Komisi Penyiaran Indonesia Tahun 2012 Pasal 9, Pasal 15 Ayat (1), dan Pasal 37 Ayat (4) huruf a. Selain itu sesuai dengan Pedoman Perilaku Penyiaran Komisi Penyiaran Indonesia Tahun 2012 Pasal 4, lembaga penyiaran juga diarahkan untuk menghormati dan menjunjung tinggi norma dan nilai agama dan budaya bangsa yang multikultural.

Kami akan melakukan pemantauan intensif kepada seluruh lembaga penyiaran. Sanksi akan kami jatuhkan jika lembaga penyiaran terbukti masih menyiarkan hal-hal di atas. Ketentuan ini berlaku bagi seluruh lembaga penyiaran agar senantiasa mengacu pada $\mathrm{P}_{3}$ dan SPS KPI Tahun 2012 dalam setiap program siarannya. Demikian surat edaran KPI Pusat ini agar diperhatikan dan dipatuhi. Terima kasih. 